\title{
Evaluating the productivity of four main tree species in Germany under climate change with static reduced models
}

\author{
Martin Gutsch $^{1}$ • Petra Lasch-Born ${ }^{1} \cdot$ Felicitas Suckow $^{1}$ • Christopher P.O. Reyer ${ }^{1}$
}

Received: 2 June 2015 / Accepted: 16 November 2015 /Published online: 2 December 2015

(C) INRA and Springer-Verlag France 2015

\begin{abstract}
- Key message We present simple models of forest net primary production (NPP) in Germany that show increasing productivity, especially in mountainous areas, under warming unless water becomes a limiting factor. They can be used for spatially explicit, rapid climate impact assessment.

- Context Climate impact studies largely rely on processbased forest models generally requiring detailed input data which are not everywhere available.

- Aims This study aims to derive simple models with low data requirements which allow calculation of NPP and analysis of
\end{abstract}

Handling Editor: Barry Alan Gardiner

Contribution of the co-authors Martin Gutsch: design of study, model simulations and analysis, interpretation of results, writing the paper. Petra Lasch-Born: design of study, interpretation of results, writing the paper. Felicitas Suckow: design of study, interpretation of results, writing the paper. Christopher Reyer: interpretation of results, writing the paper

Electronic supplementary material The online version of this article (doi:10.1007/s13595-015-0532-3) contains supplementary material, which is available to authorized users.

Christopher P.O. Reyer

reyer@pik-potsdam.de

Martin Gutsch

gutsch@pik-potsdam.de

Petra Lasch-Born

lasch@pik-potsdam.de

Felicitas Suckow

suckow@pik-potsdam.de

Potsdam Institute for Climate Impact Research (PIK), P.O. Box 6012 03, 14412 Potsdam, Germany climate impacts using many climate scenarios at a large amount of sites.

- Methods We fitted regression functions to the output of simulation experiments conducted with the process-based forest model 4C at 2342 climate stations in Germany for four main tree species on four different soil types and two time periods, 1951-2006 and 2031-2060.

- Results The regression functions showed a reasonable fit to measured NPP datasets. Temperature increase of up to $3 \mathrm{~K}$ leads to positive effects on NPP. In water-limited regions, this positive effect is dependent on the length of drought periods. The highest NPP increase occurs in mountainous regions.

- Conclusion Rapid analyses, using reduced models as presented here, can complement more detailed analyses with process-based models. Especially for dry sites, we recommend further study of climate impacts with process-based models or detailed measurements.

Keywords Forest productivity $\cdot$ Climate change

Meta-modelling $\cdot$ Scenario analysis $\cdot$ Process-based model

\section{Introduction}

Climate change influences forest ecosystems and the goods and services they provide in many ways (Alcamo et al. 2007; Lindner et al. 2010; Maroschek et al. 2009). Thus, future forests have to satisfy different and often conflicting social, ecological and economic needs under uncertain future conditions.

During the last 50 years the net primary production (NPP) of forests has increased in Europe (Ciais et al. 2008; Nemani et al. 2003; Spiecker 2002). Besides changing management, age structure, forest area and nutrient balances, climate change also partly explains this trend. Firstly, photosynthesis is not 
saturated at the current carbon dioxide concentration $\left(\mathrm{CO}_{2}\right)$ and thus tree growth may benefit from increasing atmospheric $\mathrm{CO}_{2}$ concentrations (Körner 2006; Norby et al. 2005). However, interactions between the drivers of tree growth complicate the relationship between the $\mathrm{CO}_{2}$ response of photosynthesis and growth (Körner et al. 2005; Körner 2006; Norby et al. 2010). Secondly, changes in climatic trends influence regional temperature and water balances and most likely enhance the productivity of temperate forest ecosystems at sites which are not nutrient or water limited (Boisvenue and Running 2006; Ciais et al. 2008).

On the other hand, drought stress decreases productivity and increases the predisposition to biotic (insect calamities, fungi infections) and abiotic disturbances (forest fire, storm events). For example, Norway spruce (Picea abies L. Karst.) forests impaired by drought stress are predisposed to bark beetle attacks (Wermelinger 2004).

Forest tree species are sensitive to climatic changes, and as a result, species distribution and composition may be altered (Thuiller et al. 2005). This will broaden the silvicultural portfolio in mountainous and other temperature-limited forest ecosystems. Besides these potential positive effects at the leading edge, negative effects at the trailing edge of species distributions are also reported: Scots pine (Pinus sylvestris L.) in its southernmost range may experience reduced growth and survival with modest warming (Reich and Oleksyn 2008), while beech (Fagus sylvatica L.) forests show a decrease in basal area growth due to long-term drought in the Appenines (Piovesan et al. 2008).

Consequently, numerous simulation studies strive to ascertain how sensitive global and regional forest productivity will be to climate change in forthcoming decades (e.g. Lasch et al. 2002a, b, 2005; Piao et al. 2009; Sitch et al. 2008; Reyer et al. 2014). However, these climate impact studies rely on process-based forest models which require detailed information such as soil, stand and meteorological data, which are usually not available for most sites in a region. Or, they result from global scale studies, which are of limited value for a specific region due to the coarse resolution of the models. Therefore, regional, spatially explicit studies of climate impacts on forests would benefit from models with low data requirements applicable for a large set of stands. Furthermore, to account for uncertainties associated with climate change projections, it is necessary to use a broad variety of climate change scenarios to derive probabilities of the expected impacts. In process-based models, this comes at the cost of large amounts of computing time. These limitations can be circumvented by applying simple regression models to the results of process-based models (e.g. Sallaba et al. 2015). We call these simple models here static reduced models (SRM) to distinguish this model type from time-sensitive dynamic models and complex process-based models with high data demand.
The first aim of this study was to derive SRMs for four tree species (European beech, Norway spruce, Scots pine and oaks (Quercus robur L. and Quercus petraea Liebl.)), which allow calculation of the annual average NPP. The derivation was based on annual NPP values simulated with the processbased model 4C (Lasch et al. 2005). Independent variables of the SRMs for NPP prediction were climate and soil variables across a spectrum of mono-species forest stands with different site conditions. Secondly, this study aimed to analyze the impacts of a broad variety of climate scenarios with the SRMs for the four selected tree species at a large number of sites all over Germany. Hence, we were answering two main questions: What regional trends in NPP change are projected up to 2060 in Germany and how much does the SRM-based NPP estimation vary under a broad set of climate change scenarios? This variability served as an indication of the uncertainty of different climate change scenarios.

\section{Material and methods}

\subsection{Climate data and climate scenarios}

We used observed and homogenized meteorological time series for the period 1951-2006 with a daily time resolution for 2342 meteorological stations (Österle et al. 2006) in Germany. Based on these observed daily meteorological data, climate change scenarios from 2007 until 2060 with daily resolution were generated with the statistical regional climate model STAR 2.0 (Orlowsky et al. 2007). The observed meteorological data and 50 realizations of a climate change scenario based on the A1B SRES scenario (Nakicenovic et al. 2000) with a mean temperature increase in Germany of about $2 \mathrm{~K}$ by 2060 provide the climate dataset for deriving the SRMs. The realizations are replications of the same climate change scenario with the same temperature trend but reflecting different precipitation trends.

Once the SRMs were established, we drove them with seven climate scenarios generated with STAR 2.0 assuming a $0.5 \mathrm{~K}$ stepwise increase of temperature up to $3 \mathrm{~K}$. For example, the $2 \mathrm{~K}$ climate scenario contains a temperature increase of $2 \mathrm{~K}$ in 2060 against the starting point of the scenario in 2007. For each of the seven climate scenarios $(0 \mathrm{~K}, 0.5 \mathrm{~K}, \ldots$, $3 \mathrm{~K}$ ), 50 realizations spanning a wide range of precipitation trends were available. The climate scenarios show a rather linear increase in temperature, radiation and drought index while a slight trend to lower annual precipitation sums was calculated across the climate stations between the period 1951-2006 and 2031-2060 (see Online Electronic Resources (OER) Fig. 1). It is important to note that recently, the STARS algorithm has been shown to overestimate radiation trends in future scenarios (Wechsung and Wechsung 2015). 


\subsection{Derivation of the SRM}

\subsubsection{Model runs with 4C}

We use the process-based forest growth model $4 \mathrm{C}$, which is described in more detail in OER Text 1, Lasch et al. (2005) and Reyer et al. (2014). The average annual NPP data to be used for the regression analysis were calculated separately for mono-specific stands of the four tree species with $4 \mathrm{C}$ at the 2342 climate stations in Germany. At each station, four different soil types were assumed. Hence, we simulated the average annual NPP for every tree species and soil type with the observed climate data of a climate station (1951-2006) and the future climate scenario provided by STAR 2.0 based on the A1B emission trend (2007-2060). At a lower level of detail, the soil types were parameterized for $4 \mathrm{C}$ based on four reference profiles, representing typical forest soil conditions in Germany, taken from the soil database for Germany (BÜK 1 000, BGR 1998). They differ in the amount of plant available soil water and the carbon/nitrogen ratio (Table 1) as follows:

- poor soil with low water availability (PL)

- rich soil with low water availability (RL)

- poor soil with high water availability $(\mathrm{PH})$

- rich soil with high water availability $(\mathrm{RH})$

The stands were simulated for a time period of 56 years (1951-2006) in the past and 54 years (2007-2060) in the future. The stand data for the initialization of $4 \mathrm{C}$ originate from yield tables (Table 2). We only considered young stands with an initial age of 15 years to simulate the period with the highest annual productivity of an even-aged forest stand. The simulated annual NPP was averaged over the simulation period.

To eliminate sites with extreme growing conditions such as high mountain areas, which may not be captured well by $4 \mathrm{C}$, only sites with a simulated average annual NPP value $Y_{\mathrm{NPP}, 4 \mathrm{C}}$ greater than 1 ton carbon $\mathrm{ha}^{-1}$ year $^{-1}$ were considered for deriving the species-specific regression functions. That resulted in 2340 (climate stations) times four (soil types) times two (base and future climate scenario), hence, 18,720 simulated average annual NPP values $\left(Y_{\mathrm{NPP}, 4 \mathrm{C}}\right)$ for each of the tree species.

\subsubsection{Fitting of the static reduced models}

The functions for NPP were fitted to $Y_{\mathrm{NPP}, 4 \mathrm{C}}$ dependent on climate and soil variables, which are easily available from either soil databases or climate stations. These were plant available soil water and the $\mathrm{C} / \mathrm{N}$ ratio of the soil of four reference soil profiles and the mean, minimum and maximum temperature, precipitation, radiation, relative air humidity, cloudiness and water vapour pressure, as well as aggregated climate variables such as the climatic water balance and a drought index (see below) that could be derived from these measurements. To balance the amount of independent soil and climate variables with model complexity, we decreased the amount of climate variables by forward selection. Linear models with log-transformed response and predictor variables were tested to account for nonconstant error variance and trends in the distribution. Also, polynomial terms in the drought index variable were used resulting in multiple regression functions with the same structure for all tree species:

$$
\begin{aligned}
\log Y_{\mathrm{NPP}, \mathrm{SRM}}= & \alpha+\beta_{1}\left(\log X_{W}\right)+\beta_{2}\left(\log X_{\mathrm{CN}}\right) \\
& +\beta_{3}\left(\log X_{\mathrm{T}}\right)+\beta_{4}\left(\log X_{\mathrm{R}}\right) \\
& +\beta_{5}\left(\log X_{D}\right)+\beta_{6}\left(\log X_{D}\right) 2 \\
& +\beta_{7}\left(\log X_{\mathrm{W}} \cdot \log X_{\mathrm{CN}}\right)+\varepsilon
\end{aligned}
$$

\begin{tabular}{|c|c|}
\hline$Y_{\mathrm{NPP}, \mathrm{SRM}}$ & $\begin{array}{l}\text { annual average net primary production } \\
\left(\mathrm{t} \mathrm{C} \mathrm{ha}{ }^{-1} \text { year }^{-1} \text { ) }\right.\end{array}$ \\
\hline$X_{\mathrm{W}}$ & plant available water $(\mathrm{mm})$ \\
\hline$X_{\mathrm{CN}}$ & carbon/nitrogen ratio of the soil \\
\hline$X_{\mathrm{T}}$ & mean annual temperature $\left({ }^{\circ} \mathrm{C}\right)$ \\
\hline$X_{\mathrm{R}}$ & mean annual radiation $\left(\mathrm{J} \mathrm{cm}^{-2}\right)$ \\
\hline$X_{\mathrm{D}}$ & $\begin{array}{l}\text { drought index (days), mean annual number of } \\
\text { successive days without rain in the growing } \\
\text { season }\end{array}$ \\
\hline$\psi$ & intercept of regression \\
\hline$\beta_{i}$ & regression coefficients \\
\hline & residual variance \\
\hline
\end{tabular}

The regression function's performance in comparison to the NPP values simulated with $4 \mathrm{C}\left(Y_{\mathrm{NPP}, 4 \mathrm{C}}\right)$ was assessed with
Table 1 Soil characteristics for the four soil types that were selected to represent German forest soils in this study

\begin{tabular}{llllll}
\hline Type & Symbol & Plant available water $(\mathrm{mm})$ & $\mathrm{C}_{\text {tot }}\left(\mathrm{g} \mathrm{m}^{-2}\right)$ & $N_{\text {tot }}\left(\mathrm{g} \mathrm{m}^{-2}\right)$ & $C_{\text {tot }} / N_{\text {tot }}$ \\
\hline Cambisol & PL & 143 & 19,650 & 640 & 31 \\
Cambisol & RL & 92 & 4250 & 262 & 16 \\
Cambisol & PH & 231 & 19,650 & 640 & 31 \\
Cambisol & RH & 179 & 4250 & 262 & 16 \\
\hline
\end{tabular}

$P L$ poor soil with low water availability, $R L$ rich soil with low water availability, $P H$ poor soil with high water availability, $R H$ rich soil with high water availability, $C_{\text {tot }}$ total carbon content, $N_{\text {tot }}$ total nitrogen content 
Table 2 Stand characteristics for the simulated mono-specific forest stands that were selected to represent the most productive stage of German forests (from age 15 to 70 )

\begin{tabular}{lllll}
\hline & Age (year) & $d_{\mathrm{bh}}(\mathrm{cm})$ & $h_{\mathrm{dh}}(\mathrm{m})$ & Stem number $\left(\mathrm{ha}^{-1}\right)$ \\
\hline Oak & 15 & 2.2 & 11.0 & 5734 \\
Pine & 15 & 4.6 & 7.7 & 6664 \\
Spruce & 15 & 3.3 & 6.0 & 7000 \\
Beech & 15 & 2.7 & 6.5 & 6463 \\
\hline
\end{tabular}

$d_{b h}$ mean diameter at breast height of tree, $h_{d h}$ dominant height of tree stand

the root mean squared error (RMSE), the relative root mean squared error (RMSE\%), the absolute bias (BIAS), the relative bias (BIAS\%) and the coefficient of determination $\left(R^{2}\right)$ (see OER Table 1). The distributions of the residuals were also examined. The derivation of the regression functions was conducted with the statistical software R (R Core Team 2015).

\subsection{Validation and plausibility of SRM results for NPP}

To evaluate the SRMs for each tree species, we split the $Y_{\mathrm{NPP}}$ $4 \mathrm{C}$ values into two equally-sized groups (model construction group, model validation group; Vanclay and Skovsgaard 1997). The climate stations were sorted by latitude, and every second station was reserved for the model validation group. Thus, both datasets cover the entire study area (i.e. Germany) homogenously. The $Y_{\mathrm{NPP}, 4 \mathrm{C}}$ values and their corresponding independent variables of the model construction group were used to fit the regression function (Eq. 1). The resulting functions were then run with the independent variables of the model validation group to predict the $Y_{\mathrm{NPP}, \mathrm{SRM}}$ values, and these were compared with simulated $Y_{\mathrm{NPP}, 4 \mathrm{C}}$ values of the validation group. It is important to note that the SRMs used for the climate change analysis were fitted to the full dataset as described above (see section 2.3) because validation is not possible for the future data.

To check the plausibility of the SRMs, we compared the $Y_{\text {NPP,SRM }}$ values for the 1951-2006 period with two different observed NPP datasets by Luyssaert et al. (2007) and Pretzsch (2009). These two datasets (vegetation measurements from flux tower sites and forest inventory data, respectively) provide independent estimates of the annual NPP of the four forest species used in this study.

\subsection{Experiments and analyses with the SRMs}

The SRMs were then run with the seven climate scenarios and the corresponding realizations covering a temperature increase from 0 to $3 \mathrm{~K}$ until 2060. For each climate scenario consisting of 50 realizations, the average annual NPP of the four tree species, every climate station and the four different soil types was calculated with the SRMs. The variables required to drive the SRMs (see Eq. 1) were averaged for a 30-year time period from 2031 to 2060.

For the spatial comparison of NPP, the results have been aggregated by calculating the mean average annual NPP of the climate stations belonging to the same forest eco-region (Wolff 2002; OER Fig. 2). To test the sensitivity of the SRMs to each climate factor (temperature, radiation, drought index), we varied each factor from -40 to $+100 \%$ around the total average value across all 2342 climate stations. This range covered the expected range of factors encountered in the studied area well. Only one factor was altered while the other factors were kept constant at their respective averages.

\section{Results}

\subsection{Model evaluation}

The parameters of the four species-specific SRMs are significantly different from zero and have the same order of magnitude across the different species (OER Table 2). The SRMs fit quite well to the estimates of the average annual NPP as simulated with 4C (Table 3 ). The values of NPP calculated by the SRMs are nearly unbiased, with a relative bias (BIAS\%) less than $1 \%$. The high $R^{2}$ indicates that the SRMs work equally well for all four tree species. Because the SRMs differ only slightly in their statistical characteristics for the four tree species, we show results only for Scots pine if not indicated otherwise.

Although the Bartlett-test of homogeneity of the residual variance detects significant differences between the soil groups, a visual analysis of the distribution of the data per soil group does not show a clear trend in the distribution of the residuals (OER Fig. 3). The two data clouds result from the rich and poor soils (OER Fig. 3 (left), see Table 1).

The validation results from the partitioned datasets also prove the suitability of the SRMs. The coefficient of

Table 3 Absolute and relative root mean square error (RMSE and RMSE\%) and bias (BIAS and BIAS\%) as well as coefficient of determination $\left(R_{\text {adj }}^{2}\right)$ of the average annual NPP $\left(\mathrm{t} \mathrm{C} \mathrm{ha}^{-1}\right.$ year $\left.^{-1}\right)$ calculated with the SRMs compared to $4 \mathrm{C}$ at the forest stand level

\begin{tabular}{lllll}
\hline & Beech & Oak & Pine & Spruce \\
\hline RMSE & 0.290 & 0.256 & 0.248 & 0.203 \\
RMSE\% & 5.054 & 4.662 & 3.433 & 3.964 \\
BIAS & 0.005 & 0.001 & 0.002 & 0.003 \\
BIAS\% & 0.080 & 0.016 & 0.033 & 0.050 \\
$R_{\text {adj }}^{2}$ & 0.978 & 0.984 & 0.987 & 0.988 \\
$N$ & 18,720 & 18,720 & 18,720 & 18,720 \\
\hline
\end{tabular}


Table 4 Results of the linear regression between NPP estimated with the static reduced models $\left(Y_{\mathrm{NPP}, \mathrm{SRM}}\right)$ and the corresponding results of NPP estimated with $4 \mathrm{C}\left(Y_{\mathrm{NPP}, 4 \mathrm{C}}\right)$

\begin{tabular}{lllll}
\hline & Beech & Oak & Pine & Spruce \\
\hline Equation $Y_{\mathrm{NPP}, 4 \mathrm{C}}$ & $0.98 Y_{\mathrm{NPP}}-0.2$ & $1.03 Y_{\mathrm{NPP}}-0.3$ & $0.98 Y_{\mathrm{NPP}}-0.08$ & $0.96 Y_{\mathrm{NPP}}-0.01$ \\
$R^{2}$ & 0.98 & 0.99 & 0.99 & 0.99 \\
\hline
\end{tabular}

determination $\left(R^{2}\right)$ for the linear regression between the NPP calculated with the SRM ( $\left.Y_{\mathrm{NPP}, \mathrm{SRM}}\right)$ for the model validation group and the corresponding values of NPP from $4 \mathrm{C}\left(Y_{\mathrm{NPP}, 4 \mathrm{C}}\right)$ (OER Fig. 4) is very high for all tree species (Table 4). However, for all tree species, the intercept is different from zero and the slope differs from 1 (Table 4), meaning that the relationship between the 4C-modelled and the SRM-calculated NPP differs from the perfect 1:1 line. Nevertheless, the discrepancy between the $Y_{\mathrm{NPP}, \mathrm{SRM}}$ and $Y_{\mathrm{NPP}, 4 \mathrm{C}}$ values is small.

The sensitivity analysis shows that the polynomial terms in the SRM describe the nonlinear relationship between the NPP and the drought index well (OER Fig. 5C). Similarly, the assumed log-linear relationship between NPP and temperature is obvious in the simulated $4 \mathrm{C}$ results, whereas the dependence between radiation and NPP was almost linear in the $4 \mathrm{C}$ results (OER Fig. 5A-B).

\subsection{Comparison of SRM results with observed data}

The mean annual NPP values calculated with the SRMs for the four tree species vary from 3.5 to $9.1 \mathrm{t} \mathrm{C}^{-1} \mathrm{year}^{-1}$ (Fig. 1). For Scots pine on poor soils (PL and PH, see Table 1), there is a good correspondence between the SRM and the values of Luyssaert et al. (2007) and Pretzsch (2009).

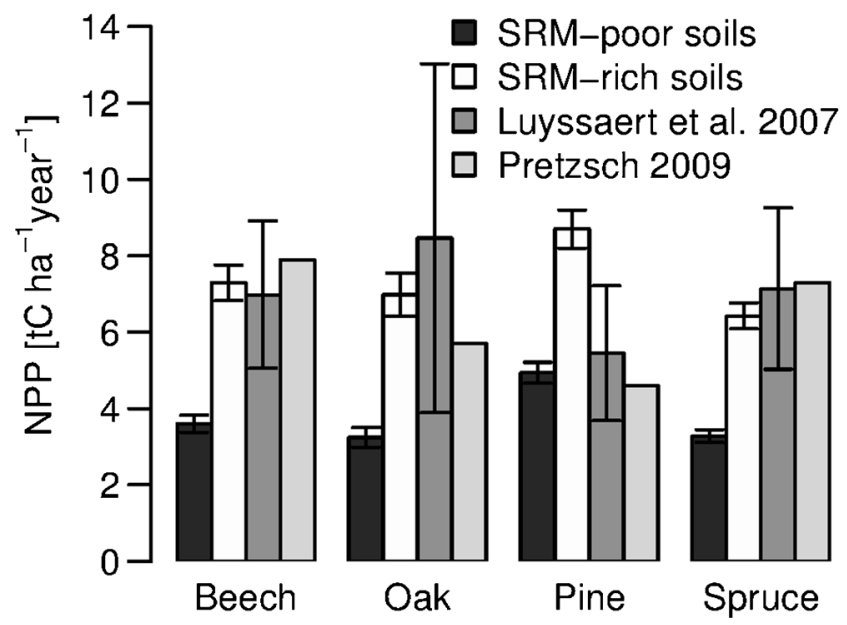

Fig. 1 Comparison of the NPP estimates for four tree species with static reduced models (SRM) on poor and rich soils and two independent observed NPP datasets by Luyssaert et al. (2007) and Pretzsch (2009). The SRM values are averaged over two types of plant available water (high and low). Error bars indicate the single standard deviation within the NPP data of one tree species
For Scots pine on rich soils (RL and RH, see Table 1), the NPP values of the SRM are the highest compared with the other tree species and larger than the observed data. Norway spruce, oak and beech show a good correspondence between SRM values and observed data for rich soil conditions. In contrast, the NPP values of the SRMs for beech, oak and Norway spruce on poor soil conditions are lower in comparison with the two measured datasets (Fig. 1).

\subsection{Overall characteristics of the net primary production calculated with the SRMs}

The tree species with the highest NPP calculated by the SRMs over the 2342 climate stations is Scots pine. The NPP of all four tree species on rich soils is around twice the NPP of the poor soils (see OER Table 3). There is almost no difference in terms of NPP between the soils with low and high plant available water (OER Table 3). The sensitivity of NPP to climate factors is most pronounced on rich soils. The range between the minimum and the maximum NPP of a forest stand at a specific climate station is smaller on poor soils (OER Table 3 ). There is an overall trend of rising NPP with increasing temperature for the analyzed stands. However, there are differences between the tree species; oak stands benefit the most while spruce stands benefit the least from temperature increase (OER Table 3).

The median of the range within a climate scenario alternates around $0.5 \mathrm{t} \mathrm{C} \mathrm{ha}^{-1}$ year $^{-1}$ for all tree species. There is a slight increasing trend of the median of the range with rising temperature. Also, the 1.5-fold interquartile distance of the ranges increases with temperature increase, except for Norway spruce (Fig. 2).

\subsection{Regional specific analyses for Scots pine}

The positive effects of climate change are stronger in mountainous regions (Fig. 3; OER Fig. 6). The lowest NPP increase for Scots pine occurs in the eastern low lands, where the median of 50 realizations with the $3 \mathrm{~K}$ scenario varies from 14 $16 \%$ (Fig. 3), and the uncertainty range across realizations is largest (Fig. 3; OER Fig. 6). The maximum spread over the 50 realizations of the $3 \mathrm{~K}$ climate scenario is $1.6 \mathrm{t} \mathrm{Cha}^{-1} \mathrm{year}^{-1}$ in the north-eastern forest eco-regions of Germany. In the southern, western and mountainous eco-regions, different realizations lead to a spread of only $0.8 \mathrm{t} \mathrm{C} \mathrm{ha}^{-1}$ year $^{-1}$ with the least variation occurring in mountainous regions (Fig. 3).

\section{Discussion}

This paper shows that SRMs, derived from a complex process-based model, provide meaningful estimates of NPP. The independent variables used in these SRMs to describe the 
Fig. 2 Box plots showing the range (maximum-minimum) of NPP $\left(Y_{\text {NPP,SRM }}\right)$ estimated by the static reduced models (SRM) for different levels of temperature increase. Each box plot represents the 50 realizations of every climate scenario for 2342 climate stations for four tree species and for site conditions of a rich soil with low water availability (RL). Boxes show the lower quartile (25\%), the median $(50 \%)$ and the upper quartile (75\%). The whiskers represent the 1.5 -fold interquartile range
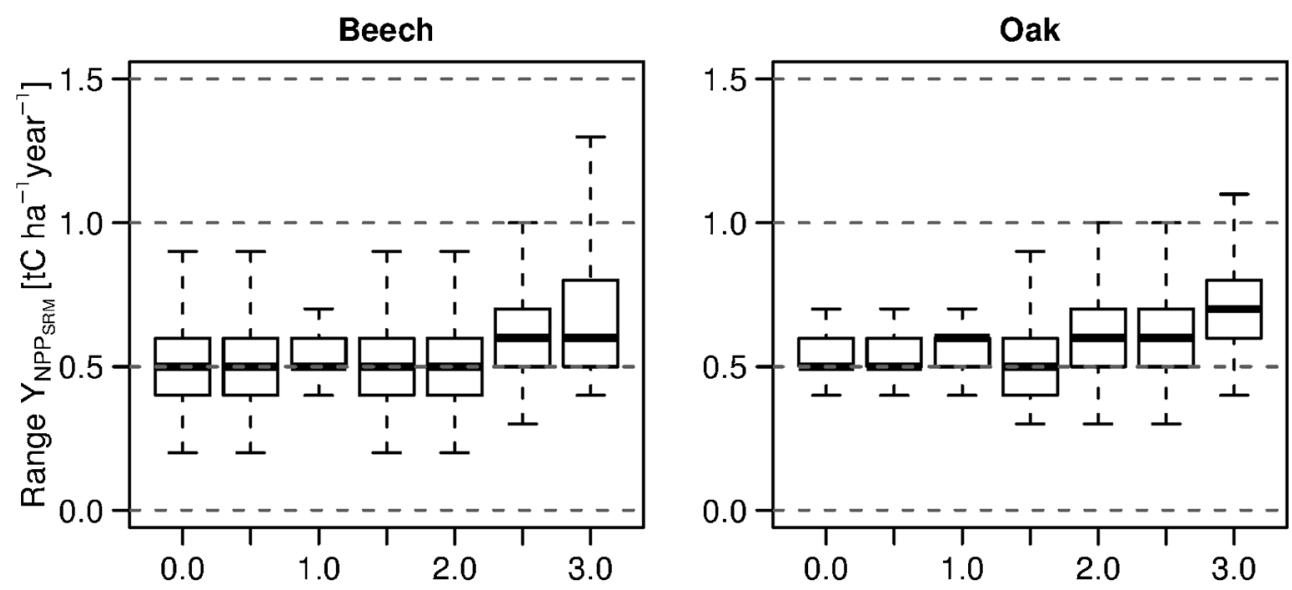

Pine

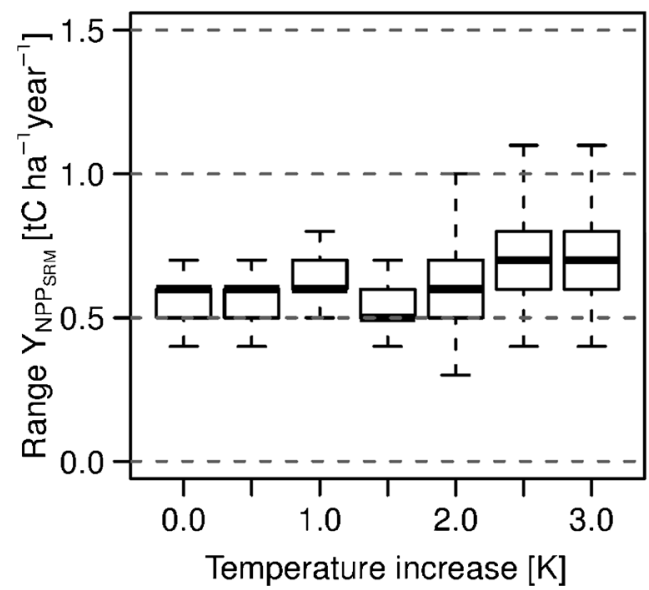

Spruce

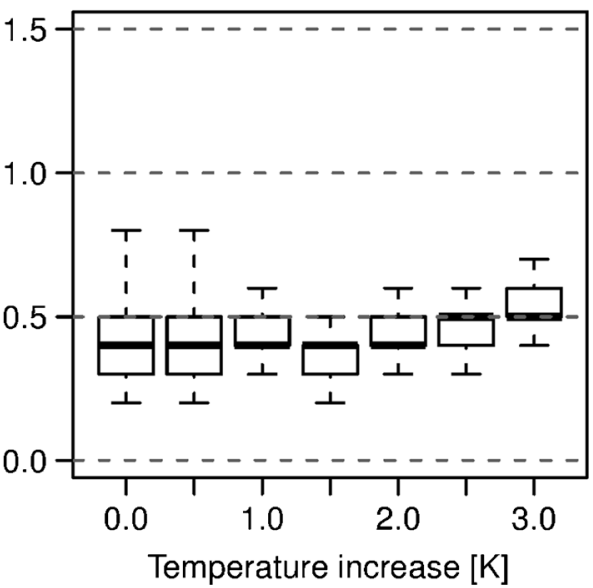

site and climatic conditions can be derived easily from basic soil databases or from meteorological data. This allows for a broad application of the SRMs as opposed to complex process-based models such as $4 \mathrm{C}$ that usually require a much more detailed soil and climate description (Fontes et al. 2010), which are not commonly available for most sites. The application of these SRMs shows that productivity under climate change increases over a wide range of climate scenarios in Germany. Below, we discuss the model evaluation, the climate change impact analysis and the general applicability of SRMs in more detail.

\subsection{Model evaluation}

The goodness of fit between simulated NPP with 4C and simulated NPP with the SRMs was very high for all tree species considered in this analysis. Despite some degree of subjectivity in choosing the soil variables (but spanning a wide range of conditions from poor to rich soils), regressions for each soil type provide high goodness of fit (results not shown). However, a more balanced data selection using soil data that covers all German soil types (currently no accessible datasets available) could change this tight relationship and introduce more variation. Regarding the problem of variance homogeneity of the residuals, we followed the suggestions of Zuur et al. (2010, see their page 6) to also add a visual analysis of significance (c.f. OER Fig. 3). In general, we note that the results of classical significance tests have to be interpreted with care when applied to large modelled datasets because they easily lead to significant differences between groups simply due to the large number of data points. For example, a randomly chosen subsample of NPP values $(n=200)$ showed no significant difference $(p>0.05)$ between different soil types even though the full dataset does show these differences (results not shown). Further studies, which compare different regression techniques, could enhance the robustness of SRMs and the understanding of underlying relationships.

The model bias and root mean square error were low, and there were only a few sites with deviations larger than $1 \mathrm{tC} \mathrm{ha}^{-}$ ${ }^{1}$ year $^{-1}$. The model validation did not reveal serious model errors (Table 4). However, the partitioning of the dataset into a model construction and a model validation dataset does not produce totally independent sets of data. Thus, the validation does not supply further information about model biases, which is also reported for other cross-validation methods (Vanclay and Skovsgaard 1997; Kozak and Kozak 2003). 


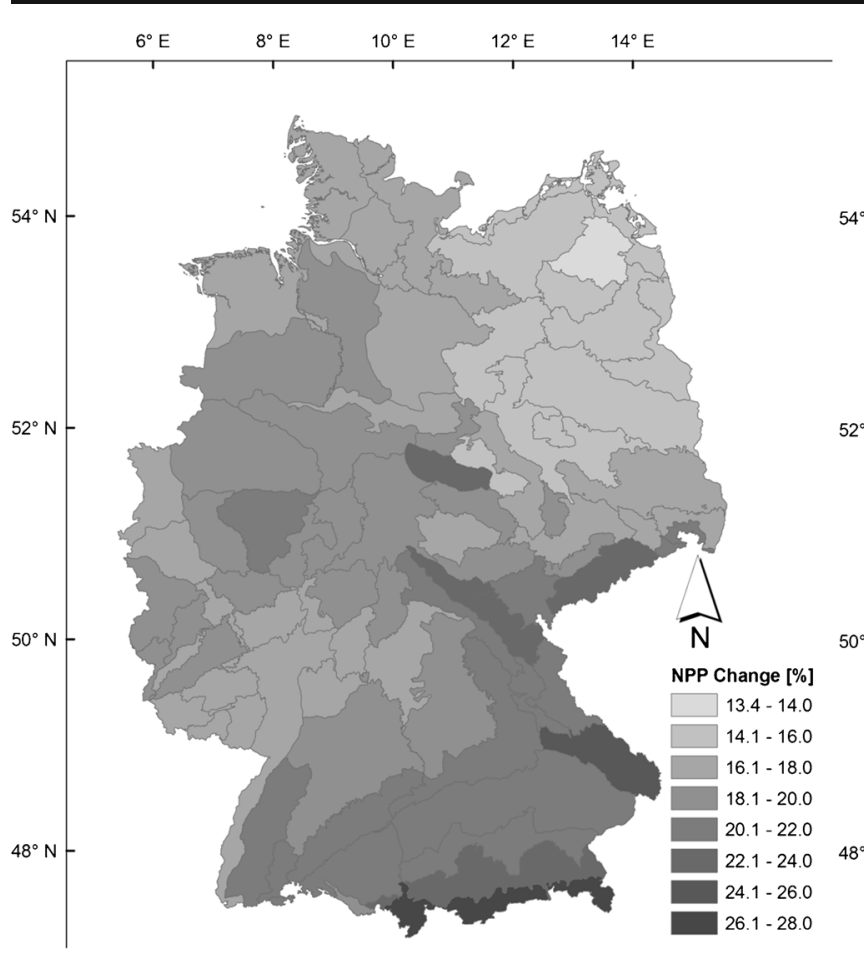

Fig. 3 Map of the interpolated, relative change in (left) and range of (right) NPP of Scots pine calculated with the static reduced model (SRM) on a typical rich soil with low water availability (RL) for 20312060 for the $3 \mathrm{~K}$ scenario. The relative change (left) refers to the

The NPP simulated with $4 \mathrm{C}$ that has been used to derive the SRMs represents only young, productive stands (age 15-70). Therefore, the NPP values calculated with the SRMs are expected to be higher than NPP for middle-aged and old forest stands. The SRMs' average mean annual NPP of 3 to $10 \mathrm{t} \mathrm{C} \mathrm{ha}^{-1}$ year $^{-1}$ is in accordance with a simulation study by Oene et al. (2000). They calculated the NPP over a broad spectrum of Norway spruce and beech forest stands in Europe ranging from 3 to $12 \mathrm{t} \mathrm{C} \mathrm{ha}^{-1} \mathrm{year}^{-1}$. Jochheim et al. (2009) simulated NPP values between 5 and $7 \mathrm{t} \mathrm{Cha}^{-1}$ year $^{-1}$ for Scots pine, beech and Norway spruce forests on nine level II plots in Germany. Similarly to our results, they found that the differences in NPP between sites are larger than between the different tree species.

In comparison with the datasets of Luyssaert et al. (2007) and Pretzsch (2009), our NPP values for Scots pine seem too high (Fig. 1). However, Scots pine stands are very often situated on less productive sites in Germany. Therefore, the SRM values for the poor sites probably represent the actual species distribution more realistically and in fact fit much better to the observed data. In the case of beech, oak and Norway spruce, the SRM values on rich sites are within the range of the two datasets. For beech and oak, this again reflects the realistic distribution of these species on forest soils. For Norway spruce, the situation is more complicated: in comparison to Scots pine, Norway spruce shows generally lower NPP values calculated with the SRMs, which is not consistent with the

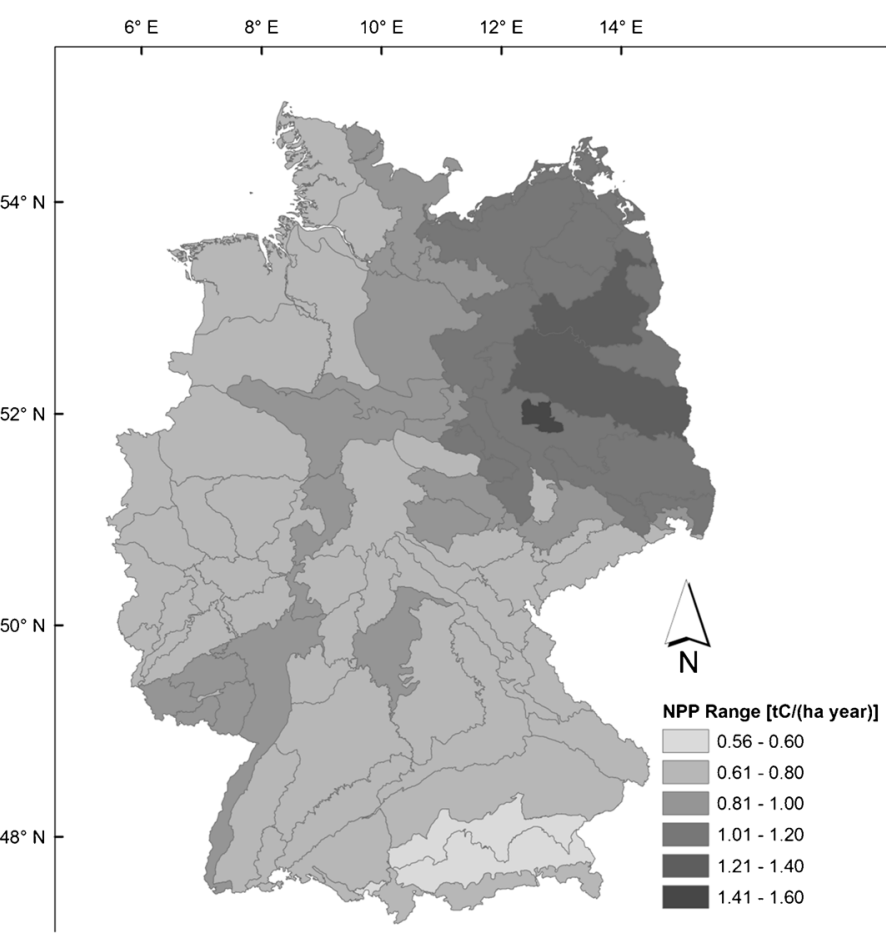

calculated NPP for 2031-2060 for the $0 \mathrm{~K}$ scenario in Germany. The range of NPP (right) is calculated for 2031-2060 over the 50 realizations. Black lines are the boundary lines for the forest eco-regions

observed data. This cannot be explained by site-specific characteristics. Here, a systematic bias in the simulated NPP with $4 \mathrm{C}$ could be present and requires further investigation. This highlights the use of the SRMs as a tool to guide further development of process-based models.

The inclusion of the $\mathrm{C} / \mathrm{N}$ ratio as a measure for nitrogen availability reflects a relationship between nitrogen availability and NPP, which was also found by Oene et al. (2000). The model $4 \mathrm{C}$ correctly simulated reduced tree productivity on poor soils mainly due to nitrogen limitation. In such situations, NPP is low and other factors such as the water supply have a small influence on the average annual NPP. On rich soils, no nitrogen limitation is simulated and climate factors such as temperature and precipitation have higher impacts on NPP, which explains the greater range of NPP values on these soils. In spite of its weak influence in this study, plant available water is usually considered an important site factor for tree productivity under climate change (Kellomaki and Wang 2000). One reason explaining our findings could be a low level of simulated drought stress from low soil water contents in $4 \mathrm{C}$. On the other hand, a strong negative correlation between the drought index greater than four and NPP for water-limited sites could be detected according to the SRMs (OER Fig. 5C). Small changes in the precipitation sum or the drought index lead to stronger responses of the SRMs in water-limited regions such as described in other studies (Gerten et al. 2008; Sang and Su 2008). The positive 
relationship between mean annual temperature and NPP in the SRMs is in good agreement with investigations in temperate forests (Boisvenue and Running 2006; Oene et al. 2000; Piao et al. 2009).

\subsection{Climate impact analysis}

For Germany, the average annual NPP calculated with the SRMs increases until 2060 for all climate scenarios and tree species. This result supports the findings of other studies that the terrestrial carbon sinks should peak around 2050 (Piao et al. 2009; Sitch et al. 2008). In Germany, two main regions could be identified where climate change impacts on NPP are most pronounced. Firstly, in mountainous regions, the temperature increase will strongly enhance the NPP. A maximum value of $28 \%$ increase of NPP for Scots pine forest stands has been calculated by the SRM for the $3 \mathrm{~K}$ scenario (Fig. 3; OER Fig. 6). In comparison, Oene et al. (2000) simulated a maximum increase in NPP of $11 \%$, when only considering the direct effects of a temperature increase of $2 \mathrm{~K}$. The different precipitation patterns of the scenario realizations only slightly affect the NPP in regions with high precipitation. Secondly, in the north-eastern lowlands of Germany, the potential temperature-induced increase of NPP is limited by the drought duration during the growing period. Here, the change in NPP under the $3 \mathrm{~K}$ scenario is accompanied by a higher uncertainty range of the scenario (Fig. 3; OER Fig. 6). The outcomes of temperature increase are site-specific. Considering the effect of temperature increase on plant water relations, a rising transpiration demand results in a more frequent stomata closure on water-limited sites, which reduces the NPP. Thus, future precipitation patterns in the realizations are particularly relevant in regions with low annual precipitation sums today. It is also important to note that these simulations do not consider the effects of changing disturbances and other extreme events that can potentially negate productivity increases driven by average temperature increase alone (Reyer et al. 2013, 2015; Seidl et al. 2014).

\subsection{Applicability of the SRMs}

Our analyses highlight the advantage of the SRMs as a tool for fast analyses of large sets of climate scenarios for a large number of sites. A simulation experiment with a set of 2342 sites, each with four soil types and four tree species, with 50 realizations of seven climate scenarios for a simulation period of 30 years with the model $4 \mathrm{C}$ would require 150 days of $\mathrm{CPU}$ time, whereas running the SRMs takes $30 \mathrm{~min}$. Furthermore, as shown above, there is less demand for input data for model application compared to a process-based model like 4C. The SRMs need only two site characteristics, which can be derived from soil databases and long-term mean values of climate data. Applying the SRMs helps to detect regions that face high climate impacts, and subsequently allow for an efficient investigation of vulnerable forest stands with more complex process-based models or targeted measurements. Thus, the SRMs do not substitute analyses with process-based models, but rather complement them.

Moreover, on a regional scale, SRMs can be used to support current studies of future forest carbon sequestration that consider stand development and management but often neglect climate change impacts (Krug et al. 2009). While in the short-term, an omission of climate effects may be acceptable because, in most cases, forest management strategies imply stronger impacts on the carbon balance of a forest than climate change, in the longer-term, this assumption of stationary conditions does not hold (Jandl et al. 2007; Gutsch et al. 2011). Therefore, for more comprehensive analyses, SRM can be coupled to forest growth models that are not climate sensitive and thus far have relied on simple scaling of growth functions to capture climate change effects (e.g. Eggers et al. 2008; Schelhaas et al. 2015).

On a global scale, our approach to derive the SRMs and their low data requirements can be used to derive simple impact functions from multi-model runs of dynamic global vegetation models. These global or continental-scale SRMs (e.g. Sallaba et al. 2015) are of increasing interest for cross-sectoral studies as part of integrated assessment model studies to assess the costs and damages from climate change at the macroeconomic level.

To increase the robustness of such analyses, integrating measurement data directly in the derivation of SRMs would be an option instead of deriving models only using simulation data. However, thus far the low variation in site conditions and species at the flux sites in Germany, the comparably short time periods covered, and limited data availability hamper such an approach. Other data sources, such as the National Forest Inventory in Germany, could provide valuable data. However, repeated measurements would be required, which are not available for all federal states in a standardized format.

There are also disadvantages to the use of SRMs. They do not allow the analysis of annual or seasonal cycles of NPP or of productivity in mixed stands. Also, questions related to reduced productivity due to biotic disturbances or extreme events in forest stands cannot be answered.

\section{Conclusions}

Static reduced models (SRM) can be used as simple impact functions to determine regional impacts on the productivity of mono-specific forest stands under climate change. The SRMs permit a spatial overview of general trends in productivity change under climate change, and thus help to identify regions which are likely to be most vulnerable. 
Running the SRMs with a broad range of temperature increases, and different precipitation levels reveal a generally positive impact on the productivity of the four main tree species in Germany. The NPP increases for all tree species with rising temperatures, especially on temperature-limited sites such as mountainous regions or on sites with high precipitation. However, beyond a $2 \mathrm{~K}$ temperature increase by 2060 , the uncertainty of NPP on water-limited forest sites also increases. Here, the results indicate a high risk of decreasing NPP for Norway spruce, Scots pine and beech. The NPP of oak on these sites is less sensitive. These rapid analyses can inform and thus complement more detailed analyses with process-based models. Especially, for water-limited or constrained sites, we recommend further analysis of climate impacts with process-based forest growth models or detailed measurements. Further research should focus on an improved validation of the SRMs with regard to soil factors and forest productivity.

Acknowledgments This work was funded by the German Federal Ministry of Education and Research (BMBF) within the project "Oakchain". We also acknowledge the support from our colleagues of Research domain IV (Transdisciplinary Concepts \& Methods) for providing excellent computational infrastructure for the simulation study. Alexander Eden is acknowledged for providing technical assistance and language checks.

\section{Compliance with ethical standards}

Funding provided This work was funded by the German Federal Ministry of Education and Research (BMBF) within the project "Oakchain".

\section{References}

Alcamo J, Moreno JM, Nováky B, Bindi M, Corobov R, Devoy RJN, Giannakopoulos C, Martin E, Olesen JE, Shvidenko A (2007) Europe. In: Parry ML, Canziani OF, Palutikof JP, van der Linden PJ, Hanson CE (eds) Climate change 2007: impacts, adaptation and vulnerability. Contribution of working group II to the Fourth Assessment Report of the Intergovernmental Panel on Climate Change. Cambridge University Press, Cambridge, pp 541-580

BGR (1998) Bodenübersichtskarte der Bundesrepublik Deutschland 1: 100.000.000 (BÜK 1000). Bundesanstalt für Geowissenschaften und Rohstoffe, Hannover

Boisvenue C, Running SW (2006) Impacts of climate change on natural forest productivity - evidence since the middle of the 20th century. Glob Chang Biol 12:862-882. doi:10.1111/j.1365-2486.2006. 01134.x

Ciais P, Schelhaas MJ, Zaehle S, Piao SL, Cescatti A, Liski J, Luyssaert S, Le-Maire G, Schulze E-D, Bouriaud O, Freibauer A, Valentini R, Nabuurs GJ (2008) Carbon accumulation in European forests. Nat Geosci 1:425-429. doi:10.1038/ngeo233

Eggers J, Lindner M, Zudin S, Zaehle S, Liski J (2008) Impact of changing wood demand, climate and land use on European forest resources and carbon stocks during the 21 st century. Glob Chang Biol 14:2288-2303. doi:10.1111/j.1365-2486.2008.01653.x
Fontes L, Bontemps J-D, Bugmann H, Van Oijen M, Gracia C, Kramer K, Lindner M, Rötzer T, Skovsgaard JP (2010) Models for supporting forest management in a changing environment. For Syst 3:8-29. doi:10.5424/fs/201019S-9315

Gerten D, Luo Y, Le Maire G, Parton WJ, Keough C, Weng E, Beier C, Ciais P, Cramer W, Dukes JS, Hanson PJ, Knapp AAK, Linder S, Nepstad D, Rustad L, Sowerby A (2008) Modelled effects of precipitation on ecosystem carbon and water dynamics in different climatic zones. Glob Chang Biol 14:2365-2379. doi:10.1111/j. 1365-2486.2008.01651.x

Gutsch M, Lasch P, Suckow F, Reyer C (2011) Management of mixed oak-pine forests under climate scenario uncertainty. For Syst 20: 453-463. doi:10.5424/fs/20112003-11073

Jandl R, Vesterdal L, Olsson M, Bens O, Badeck F, Rock J (2007) Carbon sequestration and forest management. Perspect Agric Vet Sci Nutr Nat Resour 2:1-16. doi:10.1079/PAVSNNR20072017

Jochheim H, Puhlmann M, Beese F, Berthold D, Einert P, Kallweit R, Konopatzky A, Meesenburg H, Meiwes K-J, Raspe S, SchulteBisping H, Schulz C (2009) Modelling the carbon budget of intensive forest monitoring sites in Germany using the simulation model BIOME-BGC. iForest - Biogeosciences For 2:7-10. doi: 10.3832/ ifor0475-002

Kellomaki S, Wang KY (2000) Modelling and measuring transpiration from Scots pine with increased temperature and carbon dioxide enrichment. Ann Bot 85:263-278. doi:10.1006/anbo.1999.1030

Körner C (2006) Plant $\mathrm{CO}_{2}$ responses: an issue of definition, time and resource supply. New Phytol 172:393-411. doi:10.1111/j.14698137.2006.01886.x

Körner C, Asshoff R, Bignucolo O, Hättenschwiler S, Keel SG, PeláezRiedl S, Pepin S, Siegwolf RTW, Zotz G (2005) Carbon flux and growth in mature deciduous forest trees exposed to elevated $\mathrm{CO}_{2}$. Science 309:1360-1362. doi:10.1126/science.1113977

Kozak A, Kozak R (2003) Does cross validation provide additional information in the evaluation of regression models? Can J For Res 33: 976-987. doi:10.1139/x03-022

Krug J, Koehl M, Riedel T, Bormann K, Rueter S, Elsasser P (2009) Options for accounting carbon sequestration in German forests. Carbon Balance Manage 4:1-15. doi:10.1186/1750-0680-4-5

Lasch P, Badeck FW, Lindner M, Suckow F (2002a) Sensitivity of simulated forest growth to changes in climate and atmospheric $\mathrm{CO}_{2}$. Forstwissenschaftliches Cent 121:155-171

Lasch P, Lindner M, Erhard M, Suckow F, Wenzel A (2002b) Regional impact assessment on forest structure and functions under climate change - the Brandenburg case study. For Ecol Manage 162:73-86. doi:10.1016/S0378-1127(02)00051-8

Lasch P, Badeck FW, Suckow F, Lindner M, Mohr P (2005) Model-based analysis of management alternatives at stand and regional level in Brandenburg (Germany). For Ecol Manage 207:59-74

Lindner M, Maroschek M, Netherer S, Kremer A, Barbati A, GarciaGonzalo J, Seidl R, Delzon S, Corona P, Kolström M, Lexer MJ, Marchetti M (2010) Climate change impacts, adaptive capacity, and vulnerability of European forest ecosystems. For Ecol Manage 259: 698-709

Luyssaert S, Inglima I, Jung M, Richardson AD, Reichstein M, Papale D, Piao SL, Schulze E-D, Wingate L, Matteucci G, Aragao L, Aubinet $\mathrm{M}$, Beer C, Bernhofer C, Black KG, Bonal D, Bonnefond J-M, Chambers J, Ciais P, Cook B, Davis KJ, Dolman AJ, Gielen B, Goulden M, Grace J, Granier A, Grelle A, Griffis T, Grünwald T, Guidolotti G, Hanson PJ, Harding R, Hollinger DY, Hutyra LR, Kolari P, Kruijt B, Kutsch W, Lagergren F, Laurila T, Law BE, Le Maire G, Lindroth A, Loustau D, Malhi Y, Mateus J, Migliavacca M, Misson L, Montagnani L, Moncrieff J, Moors E, Munger JW, Nikinmaa E, Ollinger SV, Pita G, Rebmann C, Roupsard O, Saigusa N, Sanz MJ, Seufert G, Sierra C, Smith M-L, Tang J, Valentini R, Vesala T, Janssens IA (2007) $\mathrm{CO}_{2}$ balance of boreal, temperate, and 
tropical forests derived from a global database. Glob Chang Biol 13: 2509-2537. doi:10.1111/j.1365-2486.2007.01439.x

Maroschek M, Seidl R, Netherer S, Lexer MJ (2009) Climate change impacts on goods and services of European mountain forests. Unasylva 60:76-80

Nakicenovic N, Davidson O, Davis G, Grübler A, Kram T, La Rovere EL, Metz B, Morita T, Pepper W, Pitcher H, Sankovski A, Shukla P, Swart R, Watson R, Dadi Z (2000) IPCC special report on emissions scenarios. Change 599:599

Nemani RR, Keeling CD, Hashimoto H, Jolly WM, Piper SC, Tucker CJ, Myneni RB, Running SW (2003) Climate-driven increases in global terrestrial net primary production from 1982 to 1999. Science 300: 1560-3. doi:10.1126/science. 1082750

Norby RJ, Delucia EH, Gielen B, Calfapietra C, Giardina CP, King JS, Ledford J, McCarthy HR, Moore DJP, Ceulemans R, De Angelis P, Finzi AC, Karnosky DF, Kubiske ME, Lukac M, Pregitzer KS, Scarascia-Mugnozza GE, Schlesinger WH, Oren R (2005) Forest response to elevated $\mathrm{CO}_{2}$ is conserved across a broad range of productivity. Proc Natl Acad Sci U S A 102:18052-6. doi:10.1073/ pnas.0509478102

Norby RJ, Warren JM, Iversen CM, Medlyn BE, McMurtrie RE (2010) $\mathrm{CO}_{2}$ enhancement of forest productivity constrained by limited nitrogen availability. Proc Natl Acad Sci U S A 107:19368-73. doi:10. 1073/pnas.1006463107

Oene HV, Berendse F, Persson T, Harrison T, Schulze E-D, Andersen BR, Bauer GA, Dambrine E, Högberg P, Matteucci G, Paces T (2000) Model analysis of carbon and nitrogen cycling in Picea and Fagus forests. In: Schulze E-D (ed) Carbon and nitrogen cycling in European forest ecosystems, 142. Springer, Berlin, pp 419-467

Orlowsky B, Gerstengarbe F-W, Werner PC (2007) A resampling scheme for regional climate simulations and its performance compared to a dynamical RCM. Theor Appl Climatol 92:209-223. doi:10.1007/ s00704-007-0352-y

Österle H, Gerstengarbe F-W, Werner PC (2006) Ein neuer meteorologischer Datensatz für Deutschland, 1951-2003. 7. Deutsche Klimatagung - Klimatrends: Vergangenheit und Zukunft. Meteorologisches Institut der Ludwig-Maximilians-Universität, München

Piao S, Friedlingstein P, Ciais P, Peylin P, Zhu B, Reichstein M (2009) Footprint of temperature changes in the temperate and boreal forest carbon balance. Geophys Res Lett 36:L07404. doi:10.1029/ 2009GL037381

Piovesan G, Biondi F, Di Filippo A, Alessandrini A, Maugeri M (2008) Drought-driven growth reduction in old beech (Fagus sylvatica L.) forests of the central Apennines, Italy. Glob Chang Biol 14:12651281. doi:10.1111/j.1365-2486.2008.01570.x

Pretzsch H (2009) From primary production to growth and harvestable yield and vice versa: specific definitions and the link between two branches of forest science. In: Forest Dynamics, Growth and Yield: From Measurement to Model. Springer, Heidelberg. 41-99.

R Core Team (2015) R: A language and environment for statistical computing. R Foundation for Statistical Computing, Vienna, Austria. URL http://www.R-project.org/

Reich PB, Oleksyn J (2008) Climate warming will reduce growth and survival of Scots pine except in the far north. Ecol Lett 11:588-97. doi:10.1111/j.1461-0248.2008.01172.x

Reyer C, Leuzinger S, Rammig A, Wolf A, Bartholomeus RP, Bonfante A, De Lorenzi F, Dury M, Gloning P, Abou Jaoudé R, Klein T,
Kuster TM, Martins M, Niedrist G, Riccardi M, Wohlfahrt G, De Angelis P, de Dato G, François L, Menzel A, Pereira M (2013) A plant's perspective of extremes: terrestrial plant responses to changing climatic variability. Glob Chang Biol 19:75-89

Reyer C, Lasch-Born P, Suckow F, Gutsch M, Murawski A, Pilz T (2014) Projections of regional changes in forest net primary productivity for different tree species in Europe driven by climate change and carbon dioxide. Ann For Sci 71:211-225. doi:10.1007/s13595-013-0306-8

Reyer C, Brouwers N, Rammig A, Brook B, Epila J, Grant RF, Holmgren M, Langerwisch F, Leuzinger S, Lucht W, Medlyn B, Pfeiffer M, Steinkamp J, Vanderwel M, Verbeeck H, Villela D (2015) Forest resilience and tipping points at different spatio-temporal scales: approaches and challenges. J Ecol 103:5-15. doi:10.1111/1365-2745. 12337

Sallaba F, Lehsten D, Seaquist J, Sykes MT (2015) A rapid NPP metamodel for current and future climate and $\mathrm{CO}_{2}$ scenarios in Europe. Ecol Model 302:29-41

Sang W, Su H (2008) Interannual NPP variation and trend of Picea schrenkiana forests under changing climate conditions in the Tianshan Mountains, Xinjiang, China. Ecol Res 24:441-452. doi: 10.1007/s11284-008-0521-1

Schelhaas M-J, Nabuurs G-J, Hengeveld G, Reyer C, Hanewinkel M, Zimmermann N E, Cullmann D (2015) Alternative forest management strategies to account for climate change-induced productivity and species suitability changes in Europe. Reg Environ Change: 114. doi: 10.1007/s10113-015-0788-Z

Seidl R, Schelhaas MJ, Rammer W, Verkerk PJ (2014) Increasing forest disturbances in Europe and their impact on carbon storage. Nat Clim Chang 4(9):806-810. doi: 10.1038/NCLIMATE2318

Sitch S, Huntingford C, Gedney N, Levy PE, Lomas M, Piao SL, Betts R, Ciais P, Cox P, Friedlingstein P, Jones CD, Prentice IC, Woodward FI (2008) Evaluation of the terrestrial carbon cycle, future plant geography and climate-carbon cycle feedbacks using five dynamic global vegetation models (DGVMs). Glob Chang Biol 14:20152039. doi:10.1111/j.1365-2486.2008.01626.x

Spiecker H (2002) Tree rings and forest management in Europe. Dendrochronologia 20:191-202. doi:10.1078/1125-7865-00016

Thuiller W, Lavorel S, Araújo MB, Sykes MT, Prentice IC (2005) Climate change threats to plant diversity in Europe. Proc Natl Acad Sci U S A 102:8245-50. doi:10.1073/pnas.0409902102

Vanclay JK, Skovsgaard JP (1997) Evaluating forest growth models. Ecol Modell 98:1-12. doi:10.1016/S0304-3800(96)01932-1

Wechsung F, Wechsung M (2015) Dryer years and brighter sky-the predictable simulation outcomes for Germany's warmer climate from the weather resampling model STARS. Int J Clim. doi:10. $1002 /$ joc. 4220

Wermelinger B (2004) Ecology and management of the spruce bark beetle Ips typographus - a review of recent research. For Ecol Manage 202:67-82. doi:10.1016/j.foreco.2004.07.018

Wolff B (2002) Processing forest inventory data to establish a nationwide database for the estimation of the impacts of climate change on German forest and forestry. Forstwiss Centralblatt 121 Suppl 1: $18-27$

Zuur AF, Ieno EN, Elphick CS (2010) A protocol for data exploration to avoid common statistical problems. Methods Ecol Evol 1:3-14. doi: 10.1111/j.2041-210X.2009.00001.x 